\title{
Luteinization and proteolysis in ovarian follicles of Meishan and Large White gilts during the preovulatory period
}

\author{
M. A. Driancourt ${ }^{1}$, H. Quesnel ${ }^{2}$, G. Meduri ${ }^{3}$, A. Prunier $^{2}$ and D. Hermier ${ }^{4}$ \\ ${ }^{1}$ INRA Reproductive Physiology, 37380 Nouzilly, France; ${ }^{2}$ INRA Pig Research, 35590 Saint-Gilles, France; ${ }^{3}$ Hôpital Bicêtre, \\ 94270 Le Kremlin Bicetre, France; and ${ }^{4}$ INRA Poultry Research, 37380 Nouzilly, France
}

This experiment was conducted to determine why follicles luteinize faster in the Meishan breed than in the Large White breed of pig. Follicles were recovered during the late follicular phase from ovaries of both breeds before and after administration of hCG given to mimic the LH surge. First, the patterns of cholesterol transporters (high and low density lipoproteins: HDL and LDL) were compared. Cholesterol transporters detected in follicular fluid consisted of HDL only. Similar amounts of Apolipoprotein A-I were found in all samples. There was no obvious breed effect on minor lipoproteins found in the HDL-rich fraction, and this pattern was altered similarly by hCG in the two breeds. The LDL-rich samples of serum from both breeds contained similar amounts of protein. Second, three steroidogenic enzymes, adrenodoxin, $17 \alpha$-hydroxylase-lyase $\left(\mathrm{P} 450_{17 \alpha}\right)$ and $3 \beta$-hydroxysteroid-dehydrogenase $(3 \beta-H S D)$ were detected by immunohistochemistry and quantified by image analysis on sections of the two largest follicles. Before hCG treatment, theca interna cells demonstrated immunoreactivities for adrenodoxin (strong), $\mathrm{P} 450_{17 \alpha}$ and $3 \beta$-HSD (very strong), whereas granulosa cells displayed immunoreactivities for adrenodoxin only. After hCG treatment, the localization of the enzymes was unchanged but the staining intensity of adrenodoxin on granulosa cells and 3 3 -HSD on theca cells increased $(P<0.01$ and $P<0.05$, respectively). Breed effects were detected for the amounts of adrenoxin in theca cells (Meishan $>$ Large White; $P<0.05$ ) and of $17 \alpha$-hydroxylase (Large White $>$ Meishan, $P<0.01)$. Breed $\times$ treatment interactions were never detected. Finally, gelatinases, plasminogen activator, plasminogen activator inhibitor, tissue inhibitors of metalloproteases (TIMP-1 and TIMP-2) were visualized by direct or reverse zymography or western blotting. Whatever the stage relative to $\mathrm{LH}$ administration, follicular fluid from Large White gilts contained more TIMP-1, and TIMP-2 $(P<0.02$ and $P<0.01$, respectively). No breed effect was detected for the amounts of gelatinases and plasminogen activator inhibitor 1 . However, for these parameters, a significant breed $\times$ time interaction was obvious, as the Meishan follicles had a greater response to hCG $(P<0.01)$. Since proteolysis plays a key role in the bioavailability of growth factors such as insulin-like growth factor 1, fibroblast growth factor and transforming growth factor $\beta$, which have the ability to alter gonadotrophin-induced progesterone production in pigs, the differences observed in its control in the present study may explain, at least in part, the different patterns of luteinization observed in Meishan and Large White follicles.

\section{Introduction}

Chinese Meishan pigs are more prolific than European Large White pigs (Legault and Caritez, 1983; Bolet et al., 1986). This appears to be largely due to an altered embryonic growth and improved embryonic development and survival (Bazer et al., 1988, 1991; Simmen et al., 1989; Wilmut et al., 1992; Anderson et al., 1993), although additional alterations of

Revised manuscript received 20 May 1998. ovulation rate have been identified in some studies (Ashworth et al., 1992, Haley and Lee, 1993). However, the mechanisms involved in these differences have not been fully clarified.

A positive relationship between progesterone secretion during the early luteal phase and embryo survival in pigs has been demonstrated (Pharazyn et al., 1991; Einarsson and Rojkittikhun, 1993; Zak et al., 1997). Plasma progesterone concentrations increase earlier after the LH surge in Meishan than they do in Large White gilts (Hunter et al., 1996) and 
follicular luteinization after hCG administration at the preovulatory stage proceeds faster in Meishan than it does in Large White gilts (Downey and Driancourt, 1994). Because this earlier progesterone increase may play a key role in the superior embryo survival of Meishan gilts, the possible mechanisms involved in follicular luteinization were compared between Meishan and Large White breeds in the present study.

A design identical to that described by Downey and Driancourt (1994), in which follicular progesterone output $16 \mathrm{~h}$ after an hCG challenge was fivefold higher in Meishan than it was in Large White gilts, was used to assess the contribution of three candidates (that is, the lipoprotein supply to follicles, the changes in amounts and localization of steroidogenic enzymes induced by hCG and hCG-induced follicular proteolysis) to this altered luteinization process. Lipoproteins are the main source of cholesterol for follicular steroidogenesis (Gore Langton and Armstrong, 1988). Furthermore, high density lipoproteins (HDL) as well as low density lipoproteins (LDL) have the ability to affect progesterone secretion by swine granulosa cells (Veldhuis et al., 1984; Rajkumar et al., 1989). Hence, an increased hCG induced lipoprotein supply to Meishan follicles may explain the faster progesterone increase in this breed. This hypothesis was addressed in the first part of the present study.

Follicular steroidogenesis in Meishan and Large White gilts has been described previously on the basis of concentrations of steroids in follicular fluid or follicle incubation media, or from cell culture studies (Hunter et al., 1993, 1994; Downey and Driancourt, 1994). However, owing to the dynamic nature of steroidogenesis, these approaches have failed to identify why breed differences occur. Available information in swine on the tissue specific localization of

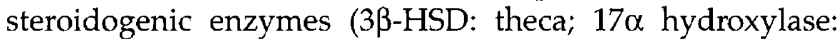
theca; P450 side chain cleavage (P450scc): theca and granulosa) (Conley et al., 1995; Meduri et al., 1996) suggests that the faster progesterone increase observed in Meishan gilts after hCG treatment could be generated either by the induction by hCG of $3 \beta$-HSD among granulosa cells in this breed or to an overall alteration in the amounts of the enzymes involved in progesterone production (P450scc, $3 \beta \mathrm{HSD})$ or utilization ( $17 \alpha$ hydroxylase). This hypothesis was explored in the second part of the study.

Since there is no evidence for differences in follicular sensitivity to LH among breeds (Biggs et al., 1993), autocrine and paracrine regulations of $\mathrm{LH}$ action on follicular steroidogenesis may differ between the two breeds studied here. At least three growth factors (insulin-like growth factor I (IGF-I): Urban et al., 1990; Caubo et al., 1989; fibroblast growth factor (FGF): Biswas et al., 1988; transforming growth factor $\beta$ (TGF $\beta$ ): Kubota et al., 1994) have the ability to alter gonadotrophin-induced progesterone secretion in pigs. However, to be active, these growth factors require proteolysis from their binding proteins (IGF-I) or release by proteolysis from the extracellular matrix (FGF) or activation by proteolysis from a latent form (TGF $\beta$ ). Some of the factors involved in the LH-induced proteolytic cascade have been characterized in pig follicles (Politis et al., 1990; Smith et al., 1994) but it is unknown whether proteolysis after an LH surge proceeds similarly in Meishan and Large White follicles. This was the last aim of the present study.

\section{Materials and Methods}

\section{Animals and experimental design}

After they had completed at least three oestrous cycles after puberty, gilts from the Meishan and Large White breeds were given an $\mathbf{1 8}$ day altrenogest (Regumate, Roussel Uclaf, Romainville) treatment to synchronize them. Hemiovariectomy was conducted under general anaesthesia induced by sodium thiopentone (Specia, Rhone Poulenc Rorer, Paris) and maintained by halothane in oxygen during the mid-late follicular phase (at day 4-5 after cessation of Regumate administration) (Downey and Driancourt, 1994). An i.m. injection of 500 iu hCG (Chorulon, Intervet, Angers) to mimic the LH surge was given $8 \mathrm{~h}$ after surgery, and the second ovary was removed at slaughter $16 \mathrm{~h}$ later, a time when early luteinization of the ovulatory follicles has been shown to have started (Downey and Driancourt, 1994).

The experiment involved 16 gilts (eight Meishan and eight Large White) in two replicates. At the time of slaughter, the respective ages of the gilts were $242 \pm 1.6$ days and $270 \pm 1.0$ (replicates 1 and 2) as opposed to $216 \pm 0.2$ and $197 \pm 0.3$ days (replicates 1 and 2) for Large White and Meishan breeds, respectively.

\section{Lipoprotein characterization}

Follicular fluid from the third and fourth largest follicles of each gilt was used (replicate 1: five gilts per breed). Samples were mixed to create pools of follicular fluid of a specific breed (Meishan or Large White) at a specific time (pre- or post-hCG) to obtain enough material for ultracentrifugation. Serum from the preovulatory period of each breed was also obtained.

One millilitre pools of follicular fluid, as well as $3 \mathrm{ml}$ pools of serum, were fractionated by ultracentrifugation in a density gradient according to the procedure described by Hermier et al., (1985). Ultracentrifugation was performed in a Beckman SW 41 rotor and a Beckman L8-55 ultracentrifuge at $200000 \mathrm{~g}$ for $48 \mathrm{~h}$ at $15^{\circ} \mathrm{C}$. After centrifugation, density gradients were fractionated by aspiration of $0.5 \mathrm{ml}$ fractions with a narrow bore pipette. Phospholipid concentration was determined in each fraction of the serum pools (but not of the follicular fluid pools owing to limited amounts of material) using an enzymatic kit (Bio Mérieux, Marcy L'Etoile) (Takayama et al., 1977) to characterize the distribution of lipoproteins along the density gradient (Hermier et al., 1985). Because the phospholipid content of lipoproteins is relatively constant (20-25\%), phospholipid concentrations in lipoprotein subfractions are good indicators of the relative proportions of the major lipoprotein classes and of their density limits.

After determination of the lipoprotein profile in serum, the LDL- and HDL-rich fractions were identified. This profile was used to identify fractions of follicular fluid to be pooled 
to form putative HDL- and LDL-rich fractions of follicular fluid. All fractions were then dialysed extensively in Spectrapor tubing (Spectrum Medical Industries, Los Angeles, CA) for $48 \mathrm{~h}$ at $4^{\circ} \mathrm{C}$ against a solution containing $0.05 \mathrm{~mol} \mathrm{NaCl} \mathrm{l}^{-1}, 0.005 \mathrm{~mol} \mathrm{NH}_{4} \mathrm{HCO}_{3} \mathrm{l}^{-1}, 0.04 \%$ (v/v) EDTA and $0.01 \%(\mathrm{v} / \mathrm{v})$ sodium azide at $\mathrm{pH} 7.4$. After quantification of the protein concentrations (Lowry et al., 1951), LDL- and HDL-rich samples from serum and follicular fluids of both lines were collected before or after hCG administration and, since they contained similar amounts of proteins, they were subjected to one-dimensional electrophoresis on $4 \%$ gel (LDL) or a $3-22 \%$ acrylamide gradient (HDL). Slab gels were then stained with silver according to the method of Henkeshoven and Dernick (1985).

\section{Immunohistochemistry}

Immunohistochemistry was conducted on the two largest follicles of each ovary (replicate 1: five gilts per breed) after they had been excised intact from the ovaries. Each specimen was coated with Tissue-Tek OCT cryoprotectant embedding medium (Miles Inc., Napperville, IL) and frozen in liquid nitrogen. Frozen sections $(6 \mu \mathrm{m})$ were cut serially at $-20^{\circ} \mathrm{C}$ with an ultramicrotome. They were air dried for $30 \mathrm{~min}$, fixed in cold acetone $\left(-20^{\circ} \mathrm{C}\right)$ for $5 \mathrm{~min}$ and allowed to dry for a further $20 \mathrm{~min}$. The sections were wrapped in cellulose and stored at $-20^{\circ} \mathrm{C}$. Furthermore, one section of each follicle was stained with Feulgen and pycnotic bodies were counted to check that all follicles sectioned were healthy.

Immunostaining was performed according to the method described by Meduri et al. (1996). This method is based on the formation of a streptavidin-biotin complex using the Vectastain ABC kit (Vector Laboratory, Burlingame, CA). Sections were rinsed in $10 \mathrm{mmol} \mathrm{PBS}^{-1}$ (pH 7.2) and incubated at room temperature for $20 \mathrm{~min}$ with sheep serum diluted at 1:20 in PBS containing 5\% (w/v) BSA, to block nonspecific background staining. Sections were then incubated overnight at $4^{\circ} \mathrm{C}$ in a moist chamber with rabbit polyclonal antibodies directed against bovine adrenodoxin (1:3000), guinea-pig $17 \alpha$-hydroxylase-lyase $\left(\mathrm{P} 450_{17 x^{\prime}} 1: 7000\right)$ and $3 \beta$-hydroxysteroid dehydrogenase ( $3 \beta-\mathrm{HSD})$ from bovine adrenal cortex (1:4000). Negative control sections were incubated with normal sheep serum (1:50). After rinsing three times for $3 \mathrm{~min}$, sections were treated with biotinylated sheep anti-rabbit IgG (1:200) for $30 \mathrm{~min}$ and with avidin-peroxidase conjugate (1:100) for $45 \mathrm{~min}$ at room temperature. The chromogen used was amino-ethylcarbazole (Sigma Chemicals, St Louis, MO) in acetate buffer containing $0.02 \%(\mathrm{v} / \mathrm{v})$ hydrogen peroxide. After counterstaining with Mayer's haematoxylin, the sections were examined under a light microscope (Leitz Diaplan).

Primary antibodies were kindly provided by E. M. Chambaz, unité INSERM 244, Centre d'études nucléaires, Grenoble France (anti 33-HSD), S. Takemori and S. Kominani, Faculty of Integrated Arts and Sciences, Hiroshima City, Japan (anti-P450 ${ }_{17 \alpha}$ ) and I. Hanukoglu, Weizmann Institute of Science, Rehovot, Israël (anti-adrenodoxin).

Immunostaining for each enzyme was conducted on all samples simultaneously and its intensity was quantified by densitometry using an image analysis system (Samba TM 2005, ALCATEL TITN, Meylan). The system was calibrated to have constant parameters for light (that is, intensity and area of light beam) throughout the experiment. Absorbance was determined in fields completely occupied by cells in the theca interna and in the granulosa of one section per follicle at 20 different $45 \mu \mathrm{m}^{2}$ locations to quantify the intensity of staining (Huet et al., 1997). Absorbance was expressed in arbitrary units. $\mathrm{P} 450_{17 \alpha}$ and $3 \beta$-HSD stainings were not homogeneous in theca interna cells. Therefore, the percentage of stained surface was determined in addition to absorbance.

Comparisons among groups were performed by analysis of variance using the general linear model procedure of SAS. A split-plot design was used with breed, animal tested within breed, time (before hCG versus after hCG) and breed $\times$ time as sources of variation. The effect of breed was tested using animal within breed as the error term, and the effects of time and breed $\times$ time were tested using the residual error term. When the influence of time was significant, a new analysis was performed within each breed, with time and animal as main effects and with the diameter of each follicle as a covariate.

\section{Study of follicular proteolysis}

This study involved the three largest follicles of each ovary obtained in the second replicate of the experiment ( $n=3$ gilts per breed). Gelatinases were demonstrated by zymography. A modified zymography was also used to assess the presence of plasminogen activator. Reverse zymography was used to demonstrate TIMP-1 and TIMP-2. Finally, the plasminogen activator inhibitor 1 (PAI-1) was demonstrated by western blot analysis.

\section{Zymography}

Samples $(5 \mu \mathrm{l})$ of follicular fluid of each follicle were assessed by zymography for gelatinase activity. SDS-PAGE was used with the addition of $1 \mathrm{mg}$ gelatin $\mathrm{ml}^{-1}$ to a $10 \%$ resolving gel (Fisher and Werb, 1990) and was achieved under non-reducing conditions. At the completion of migration, the gels were washed in $2.5 \%(\mathrm{v} / \mathrm{v})$ Triton- $\mathrm{X} 100$ twice for $30 \mathrm{~min}$, rinsed thoroughly in water and then incubated overnight in buffer $\left(50 \mathrm{mmol}\right.$ Tris- $\mathrm{HCl} \mathrm{l}^{-1}, 5 \mathrm{mmol}$ $\left.\mathrm{CaCl}_{2} \mathrm{1}^{-1} ; \mathrm{pH} 7.8\right)$. Gelatinase activity was visualized as a clear band against a blue background after staining in Coomassie blue and destaining in $30 \%$ methanol: $10 \%$ acetic acid in water.

\section{Modified zymography for plasminogen activator}

The same procedure as described above was used, except that the resolving gel contained both casein $\left(1 \mathrm{mg} \mathrm{ml}^{-1}\right)$ and plasminogen $\left(13 \mu \mathrm{g} \mathrm{m}^{-1}\right)$. Under these conditions, plasminogen is cleaved by plasminogen activators, yielding plasmin which then degrades the casein (Fisher and Werb, 
1990). The areas containing enzyme are clear against a blue background. Again, all samples ( $5 \mu 1$ per lane) were run on an individual basis.

\section{Reverse zymography}

Follicular fluids were analysed for the presence of TIMP, on mini gels, of $1 \mu \mathrm{l}$ samples by zymography after SDS-PAGE $\left(10 \%\right.$ gel containing $1 \mathrm{mg}$ gelatin $\mathrm{ml}^{-1}$ and a metalloprotease (MMP) preparation) under non-reducing conditions. A kit purchased from University Technologies International (Calgary, Alberta) was used for this purpose. After washing in a solution of $2.5 \%$ Triton-X100, $50 \mathrm{mmol}$ Tris $\mathrm{l}^{-1}(\mathrm{pH} 7.5)$ and $5 \mathrm{mmol} \mathrm{CaCl}_{2} \mathrm{l}^{-1}$, the gel was incubated for $24 \mathrm{~h}$ in the same buffer without Triton-X100. The gel was stained with Coomassie blue and the presence of TIMP was visualized by the presence of dark bands on a clearer background. Standards (provided with the kit) helped to establish the presence of TIMP in the samples.

\section{Western blotting}

A subsample (from the two largest follicles before LH and the two largest follicles after LH) of follicular fluid of each gilt was used. Follicular fluid samples $(5 \mu \mathrm{l})$ were fractionated with SDS-PAGE under reducing conditions. Proteins were electrotransferred onto a nitrocellulose filter $\left(0.2 \mu \mathrm{m}\right.$ pore size) overnight at $4^{\circ} \mathrm{C}$. After electrotransfer, filters were incubated for $2 \mathrm{~h}$ at room temperature with 20 mmol Tris-buffered saline (TBS) $\mathrm{l}^{-1}(\mathrm{pH} \mathrm{7.6)}$ containing $10 \%$ non-fat dry milk powder (NFDMP) and $0.2 \%(\mathrm{v} / \mathrm{v})$ Tween 20 to saturate non-specific binding sites. Thereafter, the filters were incubated for $1 \mathrm{~h}$ at $37^{\circ} \mathrm{C}$ with the primary antibody (rabbit anti-human PAI-1, American Diagnostica, final dilution 1:750) for $2 \mathrm{~h}$ at $37^{\circ} \mathrm{C}$ in TBS containing $5 \%$ NFDMP. This procedure was followed by two washes in TBS containing $10 \%$ NFDMP and $0.2 \%$ Tween 20 . Filters were then incubated for $1 \mathrm{~h}$ at $37^{\circ} \mathrm{C}$ in TBS containing $5 \%$ NFDMP and peroxidase-labelled goat anti-rabbit IgG (final dilution 1:1000) (Sanofi Pasteur, Paris). The signal was revealed by enhanced chemiluminescence (ECL) (Amersham, Les Ulis).

\section{Image and data analysis}

Dark bands present on the reverse zymographs and on the blots were scanned and the magnitude of the signal in each lane was qualified by image analysis (Kepler Software, Large Scale Biology, Rockville, TN) as described by Driancourt et al. (1996). The signal obtained on the zymograms for gelatinases and for plasminogen activator were white. Scanning and qualification were achieved as described above, except that the amounts of signal (which were negative because the bands were white) are presented as absolute values.

All data regarding proteolysis were analysed by ANOVA for breed and time relative to hCG effects as well as breed $\times$ time interactions. Gilt within breed was entered in the model and breed effects were tested using the later residual.

\section{Results}

\section{Follicular features}

The average (mean of the three largest follicles) follicular diameters (pooled over the two replicates) of the Large White follicles were $6.3 \pm 0.2$ and $7.2 \pm 0.2 \mathrm{~mm}$ before and after hCG administration, respectively. The corresponding values for Meishan follicles were $6.1 \pm 0.1$ and $6.6 \pm 0.1 \mathrm{~mm}$ before and after hCG administration, respectively (Large White $>$ Meishan after hCG administration; $P<0.05$ ). None of the gilts in the groups had initiated their LH surge before hCG administration, as evidenced by circulating concentrations of $1.2 \pm 0.04$ and $1.2 \pm 0.13 \mathrm{ng} \mathrm{ml}^{-1}$ (Large White and Meishan gilts, respectively) measured in the $\mathrm{LH}$ assay described and validated by Camous et al. (1985).

\section{Lipoprotein characterization in follicular fluid and serum}

The serum lipoprotein profile deduced from the determination of phospholipids in each fraction from Meishan and Large White serum allowed identification of LDL and HDL (the two major peaks) on the basis of density (Fig. 1). For electrophoresis, fractions were pooled as follows: LDL-rich fraction (fractions 1-9: density $<1.055$ arbitrary units) and HDL-rich fraction (fractions 12-16: 1.075< density $<1.145$ arbitrary units). The last phospholipid peak (fractions 19-22: density $>1.180$ arbitrary units), of which lipid moiety consisted almost exclusively of phospholipids and contained mostly serum proteins, was not studied. Detectable amounts of proteins could be measured in the LDL-rich fraction of serum samples $\left(0.235\right.$ and $0.241 \mathrm{mg} \mathrm{ml}^{-1}$ in Meishan and Large White serum, respectively), but not in the follicular fluid samples, whatever the time of sampling and the breed. The resolution of the LDL from serum on onedimensional gels showed that amounts of Apolipoprotein B were similar between the two breeds (data not shown). Protein concentrations in the HDL-rich fraction of serum were 0.554 and $0.574 \mathrm{mg} \mathrm{ml}^{-1}$ in Meishan and Large White females, respectively. In both breeds, hCG administration induced a clear decrease in the protein concentrations of the HDL-rich fraction of follicular fluid (Meishan before hCG: $0.685 \mathrm{mg} \mathrm{ml}^{-1}$; Meishan after hCG: $0.302 \mathrm{mg} \mathrm{ml}^{-1}$; Large White before hCG: $0.723 \mathrm{mg} \mathrm{ml}^{-1}$; Large White after hCG: $0.370 \mathrm{mg} \mathrm{ml}^{-1}$ ). The HDL-rich samples were submitted to one-dimensional PAGE and silver staining (Fig. 2). In all HDL-rich samples, a major band corresponding to the molecular weight of Apolipoprotein AI was detected at $28 \mathrm{kDa}$, the intensity of which was similar in all samples. An additional major band was detected with a molecular mass typical of Apolipoprotein AIV (46 kDa) in serum samples and as a doublet of $43-45 \mathrm{kDa}$ in follicular fluid samples. There was no breed effect on the amounts of proteins corresponding to this doublet but hCG administration appeared to increase the amounts of the $45 \mathrm{kDa}$ band and to 


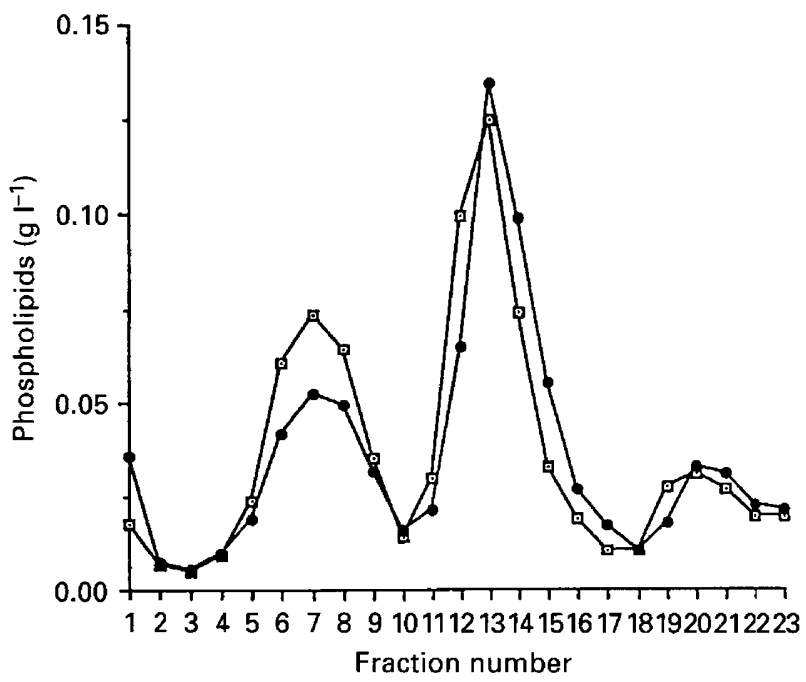

Fig. 1. Serum lipoprotein profile deduced from determination of phospholipid concentrations in successive fractions of a density gradient from serum of Meishan ( $\square$ ) and Large White (๑) gilts. Fraction 1 is the top fraction containing very low density lipoproteins.

decrease that of the $43 \mathrm{kDa}$ band in both breeds (Fig. 2). The $43 \mathrm{kDa}$ band was missing in the serum samples. Additional proteins affected by hCG administration (but not by breed) were found at $23 \mathrm{kDa}$ and $11 \mathrm{kDa}$, the latter corresponding to the molecular mass of Apolipoprotein Cs. Apolipoprotein E (molecular mass, $34 \mathrm{kDa}$ ) was not detected in any sample.

\section{Immunohistochemistry}

Before hCG treatment, theca interna cells demonstrated immunoreactivities for adrenodoxin (strong), $\mathrm{P} 450_{17 \alpha}$ and $3 \beta$-HSD (very strong) whereas granulosa cells displayed immunoreactivities for adrenodoxin only (Fig. 3). After hCG treatment, localization of the enzymes was unchanged. Quantitative estimates of the amounts of each enzyme were obtained after image analysis and compared (Tables 1 and 2). No breed $x$ time interaction was obvious for any enzyme in granulosa or theca cells (Tables 1 and 2). Meishan follicles displayed higher amounts of adrenodoxin in theca cells and, to a smaller extent, in granulosa cells than did Large White follicles $(P<0.05)$ (Table 1$)$. However, amounts of $\mathrm{P} 450_{17 \alpha}$ were significantly increased in Large White compared with Meishan follicles, irrespective of the time relative to hCG administration (Table 2). Administration of hCG altered the amounts of adrenodoxin in granulosa cells $(P<0.01)$ and of $3 \beta$-HSD in theca cells $(P<0.05$; Tables 1 and 2$)$.

\section{Study of follicular proteolysis}

When follicular fluid samples were loaded onto an acrylamide gel containing gelatin (zymography), a clear signal at $92 \mathrm{kDa}$ was present in all samples. Significant amounts of other gelatin-degrading proteases at lower

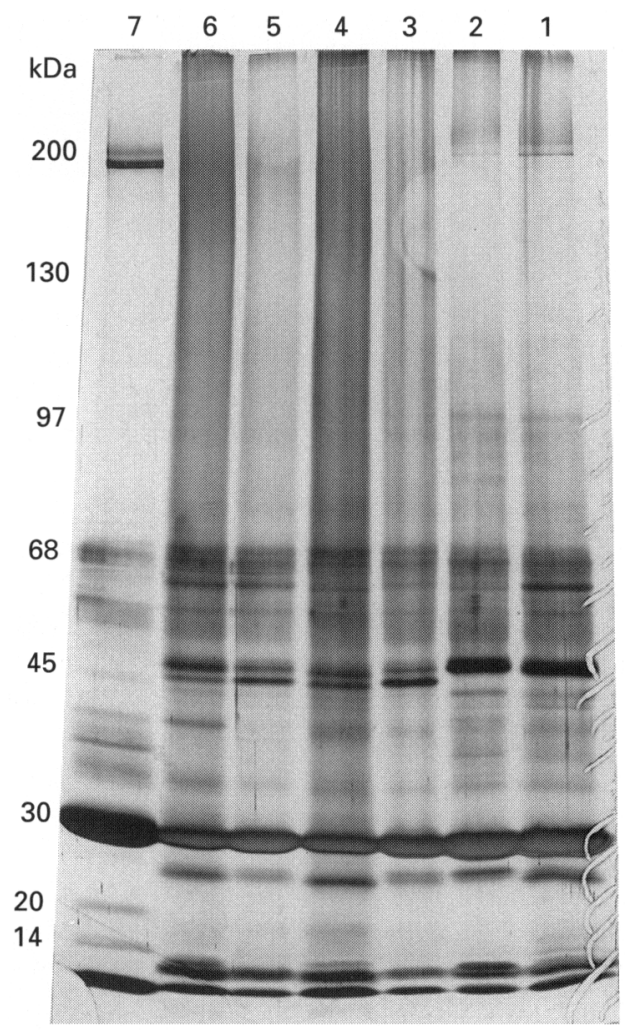

Fig. 2. One-dimensional separation (3-22\% gradient) of the lipoproteins contained in the high density lipoprotein rich fractions of the serum and follicular fluid of Meishan and Large White breeds of gilt before and after administration of hCG. Molecular mass markers $(\mathrm{kDa})$ are shown on the left. Lane 1, high density lipoproteins (HDLs) from Meishan serum; lane 2, HDLs from Large White serum; lane 3, HDLs from Meishan follicular fluid collected before hCG administration; lane 4, HDLs from Meishan follicular fluid collected after hCG administration; lane 5, HDLs from Large White follicular fluid collected before hCG administration; lane 6, HDLs from Large White follicular fluid collected after hCG administration. For comparison, HDLs from human serum are shown in lane 7.

molecular mass could not be visualized in samples of specific groups. Analysis of the magnitude of the absolute value of the signal by ANOVA revealed a significant effect of hCG administration $(P<0.01)$ and a significant breed $\times$ time interaction $(P<0.01)$, as the amounts of gelatinase increased sevenfold after hCG administration in Meishan follicles, while increasing only 1.5 -fold in Large White follicles (Fig. 4).

When follicular fluid samples were loaded on an acrylamide gel containing casein and plasminogen to detect plasminogen activator, a single clear signal of $80 \mathrm{kDa}$ resulted. Analysis of the magnitude of the signal by ANOVA demonstrated no significant main effects but an interaction between breed and hCG $(\mathrm{P}<0.01)$. Follicular fluid from Large White follicles contained twice the amounts of plasminogen activator as that of Meishan follicles before hCG administration, but this difference was reduced after hCG administration (Fig. 5).

TIMP-1 and TIMP-2 were identified by reverse zymog- 

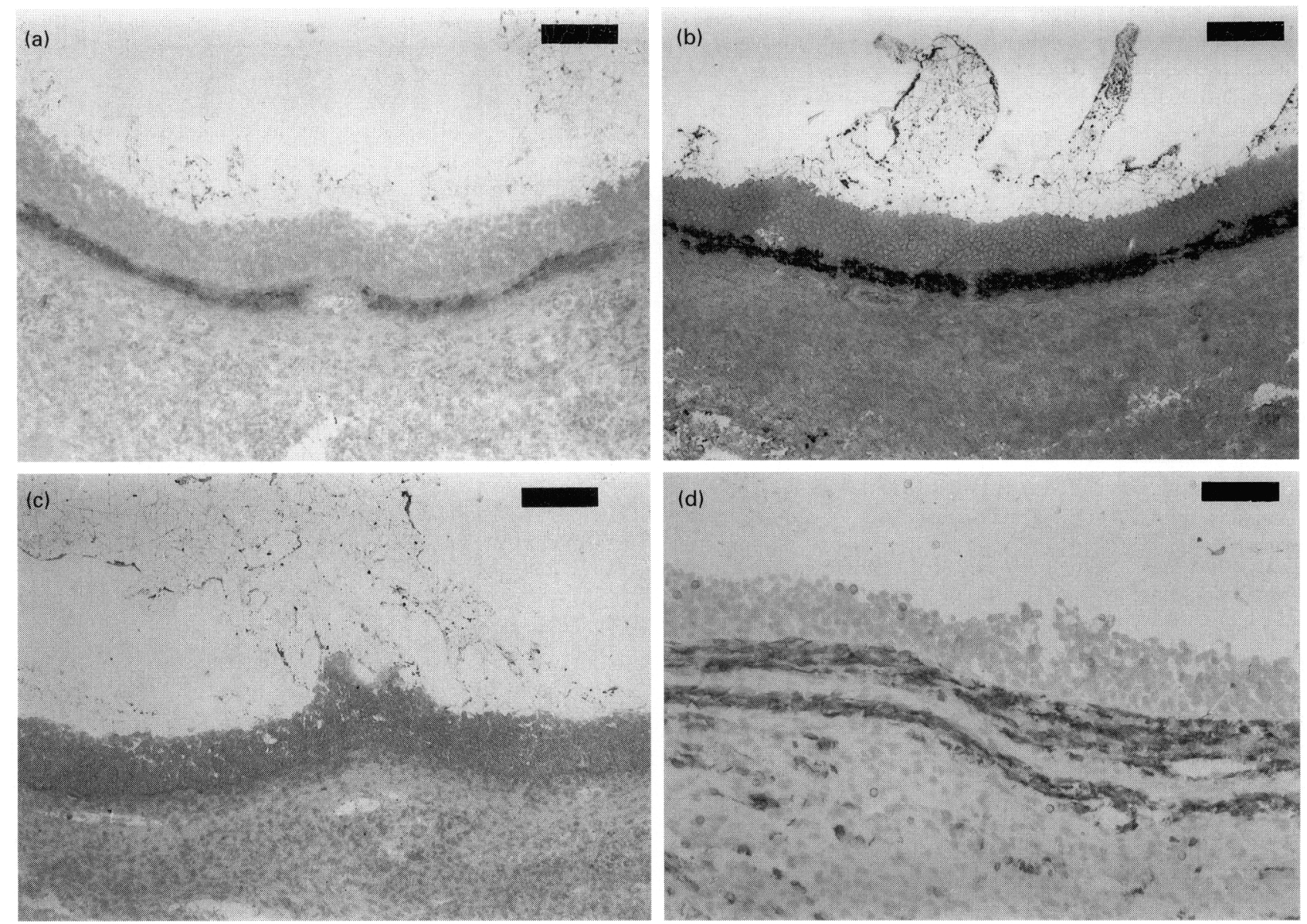

Fig. 3. Patterns of immunoreactive (a) adrenodoxin, (b) $\mathrm{P} 40_{17 \alpha^{\prime}}$ (c) $\mathrm{P} 450$ aromatase, and (d) $3 \beta$-HSD observed before hCG administration on follicles from Large White gilts. The localization of these enzymes was similar in follicles from Meishan gilts. Scale bars represent $100 \mu \mathrm{m}$.

raphy. In most of the samples of Large White follicular fluid and in part of the samples of Meishan follicular fluid, two bands (at $29 \mathrm{kDa}$ and at $24 \mathrm{kDa}$ ) were detected. Inclusion of TIMP standards in the gel established that the bands observed were TIMP-1 and TIMP-2, respectively. Statistical analysis of the data demonstrated a significant breed effect $(P<0.02)$ and a significant $(P<0.05)$ breed $\times$ time interaction (Fig. 6) for TIMP-1, since TIMP-1 amounts increased after hCG in Large White follicles, while remaining low and steady in Meishan follicles after hCG administration (Fig. 6). A significant effect $(P<0.01)$ of the breed and a significant breed $\times$ time interaction $(P<0.01)$ were detected for TIMP- 2 . TIMP-2 concentrations were higher in Large White follicles, and an increase after hCG was noted only in Meishan follicles.

Plasminogen activator inhibitor 1 in follicular fluid was identified and quantified by western blot. After chemiluminescence (ECL) revelation, a single band was obvious on the films (data not shown). Quantification of the signal demonstrated a significant breed $\times$ hCG administration interaction $(P<0.01)$, as the induction of PAI1 by hCG was larger in Meishan follicles compared with Large White follicles.

\section{Discussion}

The aim of this study was to compare the effects of an $\mathrm{LH}$ surge (mimicked by hCG injection) on the final preovulatory maturation of follicles belonging to Meishan and Large White gilts to determine which mechanisms are involved in the earlier luteinization of Meishan compared with Large White females. Three possible hypotheses for this faster luteinization that relate to the cholesterol supply to follicles, to the amounts of steroidogenic enzymes and to the mechanisms controlling follicular proteolysis were studied in the present work.

Whether cholesterol supply to follicles is affected by breed or time relative to hCG has not been clarified before. Lipoproteins constitute the most abundant source of cholesterol for steroidogenesis (Gore Langton and Armstrong, 1988). Both LDL and HDL appear to be able to modulate progesterone secretion of swine granulosa cells in vitro (Veldhuis et al., 1984; Rajkumar et al., 1989). However, since LDL do not gain access to follicular fluid (Chang et al., 1976; Veldhuis et al., 1984), only HDL are likely to be involved in the control of progesterone secretion by granulosa cells in vivo. In contrast, because the theca layer is 
Table 1. Mean absorbance, expressed in arbitrary units (mean \pm SEM), of adrenodoxin staining in theca interna cells and granulosa cells of large follicles of Large White and Meishan gilts before and after hCG treatment

\begin{tabular}{llcc}
\hline \multirow{2}{*}{ Treatment } & Breed & Theca interna cells & Granulosa cells \\
\cline { 3 - 4 } & & $36.0 \pm 4.4$ & $29.6 \pm 2.8$ \\
Before hCG & Large White & $60.2 \pm 12.9$ & $40.8 \pm 4.8$ \\
& Meishan & $43.9 \pm 14.3$ & $39.5 \pm 11.6$ \\
After hCG & Large White & $56.5 \pm 7.2$ & $50.1 \pm 6.4$ \\
& Meishan & Breed & \\
Significance & & Breed NS \\
& & Treatment NS & Treatment \\
& & $B \times$ T NS & B $\times$ T NS \\
\hline
\end{tabular}

"Statistical significance of breed, hCG treatment or the interaction breed $\times$ treatment $(\mathrm{B} \times \mathrm{T})$ indicated by ${ }^{*} P<0.01 ;{ }^{*} P<0.05$ and $\mathrm{NS} P>0.10$.

highly vascularized, both LDL and HDL from serum may affect steroidogenesis by theca cells in vivo. There was no breed difference in the pattern of LDL in serum visualized after ultracentrifugation and one-dimensional electrophoresis. One-dimensional patterns of the HDL-rich fractions were compared between the two breeds at specific times relative to hCG. The protein profile of the follicular fluid samples was close to that reported by Veldhuis et al. (1984). Apolipoprotein AI and a doublet at 43-45 kDa were the main components of the HDL-rich fraction in both breeds. The 43 $\mathrm{kDa}$ band was present in follicular fluid but was not detected in the serum samples. Its origin (possibly by proteolysis) requires further investigation. In contrast to the situation in rats (Nicosia et al., 1992), ovarian production of Apolipoprotein $\mathrm{E}$ was not detected. The ratio between the amounts of the two forms of the $43-45 \mathrm{kDa}$ doublet appeared to be modified by hCG administration. However, this effect was similar in the two breeds. Other low molecular mass bands were also modified by hCG but not by breed. In addition, it was noted that the amounts of proteins present in the HDL-rich fraction of follicular fluid of both breeds were reduced by hCG administration, which may reduce the cholesterol supply to luteinizing granulosa cells. Alternatively, this reduction in the HDL-rich fraction could be a consequence of increased binding of HDL to follicular cells after hCG administration. In any case, the similarities between breeds in the patterns of HDL in follicular fluid and serum, and in the amounts of HDL and LDL in serum, do not support the hypothesis that a different cholesterol supply to follicles plays a major role in generating the faster luteinization found in Meishan follicles.

It has not been investigated previously whether amounts of steroidogenic enzymes differ between Meishan and Large White follicles before or after an ovulatory hCG signal. Extensive information is available on steroidogenesis in pig follicles based on follicular fluid concentrations (Foxcroft and Hunter, 1985; Hunter et al., 1993) or cell culture studies (Evans et al., 1981; Stoklosowa et al., 1982; Tsang et al., 1985; Hunter et al., 1994). Furthermore, data from northern blots on mRNAs for steroidogenic enzymes (Conley et al., 1994; Guthrie et al., 1994) have largely confirmed this information. Comparison of the amounts of specific steroidogenic enzymes in Meishan and Large White follicles using semi-quantitative immunohistochemistry has not been undertaken previously. Image analysis of ovarian sections of sheep (Huet et al., 1997) using the same software proved useful for quantitating steroidogenic enzymes in follicular walls. Because heterogeneity within the granulosa (Lahteemaki et al., 1982) and theca layers, indicated by the use of morphological or functional (LH receptors) markers (Meduri et al., 1992), has been reported in gilts, an approach retaining this heterogeneity (that is, immunohistochemistry on intact follicles) was selected. The location of $\mathrm{P}_{450} 0_{17 \alpha}$ and $3 \beta$-HSD in large follicles was similar to that described by Conley et al. (1995) and Meduri et al. (1996). The location of the enzymes studied was similar in both Meishan and Large White gilts, whereas the staining intensity of adrenodoxin and $P 450_{17 \alpha}$ differed slightly between breeds. The lower $P 450_{17 \alpha}$ content in Meishan gilts is in agreement with the lower basal testosterone production observed by Downey and Driancourt (1994) in preovulatory follicles. Adrenodoxin belongs to the enzymatic complex catalysing the conversion of cholesterol to pregnenolone, which is the first and rate-

Table 2. Percentage of stained surface and mean absorbance, expressed in arbitrary units, of $17 \alpha$-hydroxylase-lyase (P450 $17 \alpha)$ and $3 \beta$-hydroxysteroid-dehydrogenase ( $3 \beta-H S D)$ (mean \pm SEM) in theca interna cells of large follicles of Large White and Meishan gilts, before and after hCG treatment

\begin{tabular}{|c|c|c|c|c|c|}
\hline Treatment & Breed & \multicolumn{2}{|c|}{$P 450_{17 \alpha}$} & \multicolumn{2}{|c|}{$3 \beta-H S D$} \\
\hline \multirow[t]{2}{*}{ Before hCG } & Large White & $51.5 \pm 23.8$ & $81.3 \pm 5.2$ & $34.8 \pm 13.5$ & $52.2 \pm 2.8$ \\
\hline & Meishan & $35.8 \pm 16.2$ & $76.4 \pm 2.6$ & $30.7 \pm 23.0$ & $53.2 \pm 3.2$ \\
\hline After hCG & Large White & $69.5 \pm 17.5$ & $88.2 \pm 7.6$ & $57.0 \pm 8.7$ & $59.7 \pm 4.5$ \\
\hline \multirow{2}{*}{ Significance ${ }^{a}$} & & Treatment NS & Treatment NS & Treatment* & Treatment ${ }^{*}$ \\
\hline & & $\mathrm{B} \times \mathrm{TNS}$ & $\mathrm{B} \times \mathrm{TNS}$ & $\mathrm{B} \times \mathrm{TNS}$ & $\mathrm{B} \times \mathrm{T} N \mathrm{NS}$ \\
\hline
\end{tabular}

a Statistical significance of breed, $\mathrm{hCG}$ treatment or the interaction breed $\times$ treatment $(\mathrm{B} \times \mathrm{T})$ indicated by ${ }^{* *} P<0.01 ;{ }^{*} P<0.05 ; P<0.10$ and NS $P>0.10$. 


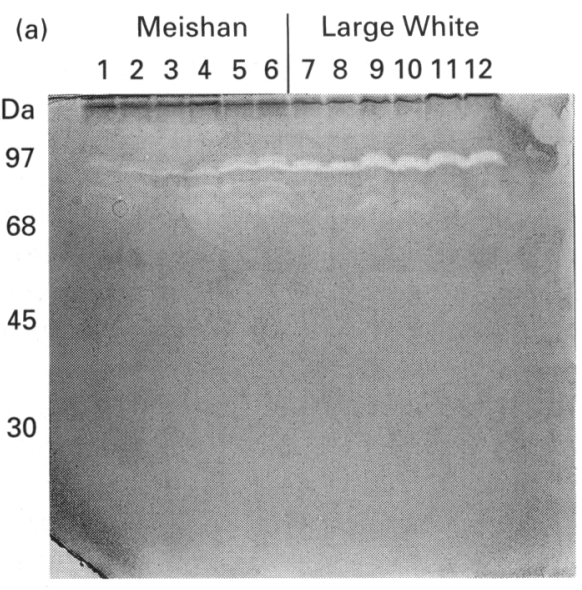

(b)
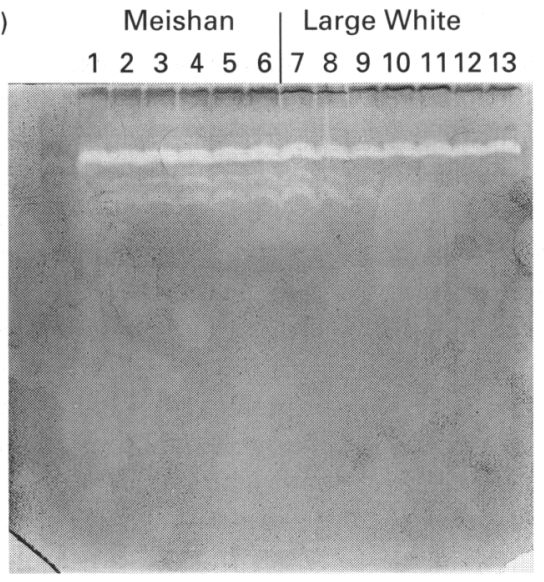

(c)

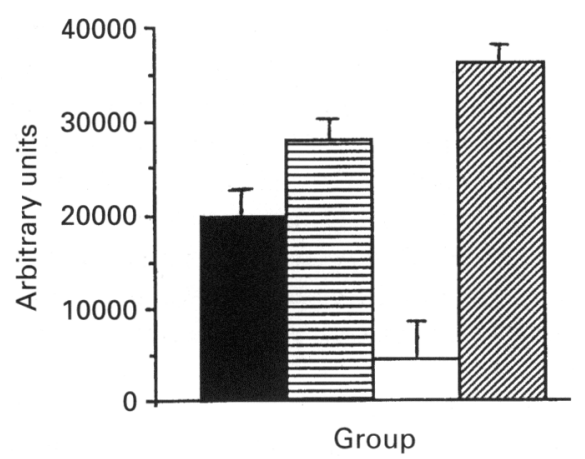

Fig. 4. Visualization of gelatinases in the follicular fluid of follicles from Large White and Meishan gilts before (a) and after (b) hCG administration. Molecular mass markers are shown on the left. (a) Lanes 1-6 contain $5 \mu 1$ Meishan follicular fluid, while lanes 7-12 contain $5 \mu \mathrm{l}$ Large White follicular fluid, obtained before hCG administration. (b) Lanes 1-6 contain $5 \mu \mathrm{l}$ Meishan follicular fluid, while lanes 7-13 contain $5 \mu 1$ Large White follicular fluid, obtained after hCG administration. (c) Densitometry analysis of all samples. 口, Large White before hCG; $\Xi$, Large White after hCG; $\square$, Meishan before hCG; $\mathbb{Z}$, Meishan after hCG.

limiting step in the biosynthesis of steroid hormones. The greater amount of adrenodoxin in Meishan large follicles may contribute to the provision of more substrate for steroidogenesis. Since $\mathrm{P}^{4} 50_{17 \alpha}$ is less abundant in Meishan (a)

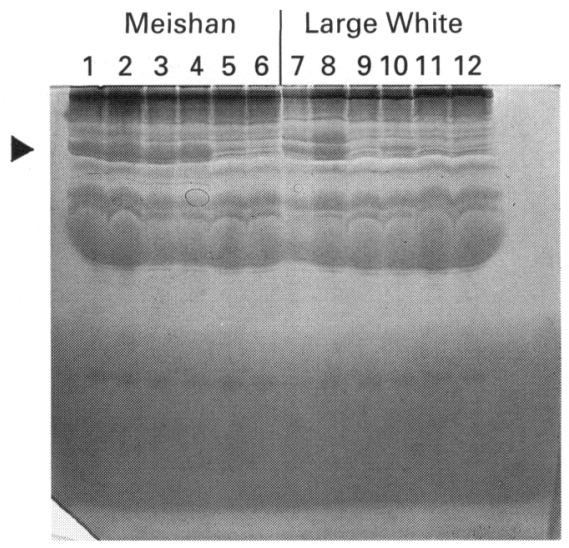

(b)
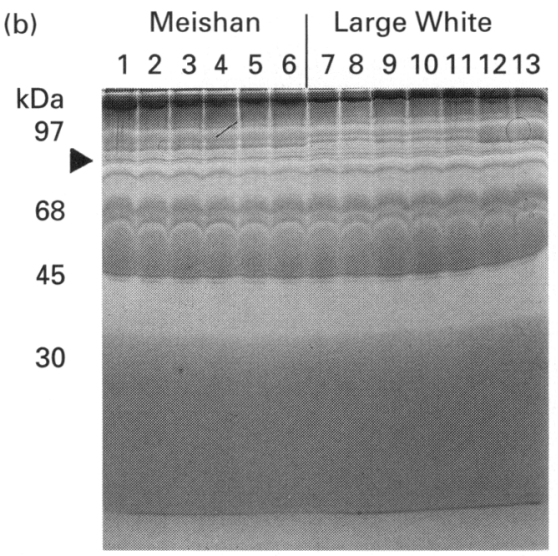

(c)

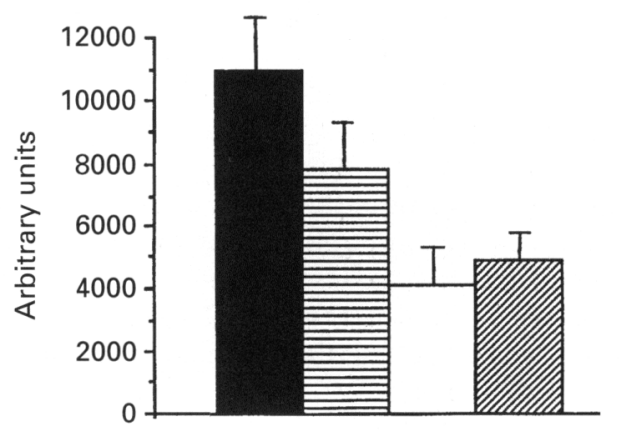

Group

Fig. 5. Visualization of tissue-type plasminogen activator ( $t P A)$ in the follicular fluid of Large White and Meishan gilts before and after hCG administration. Molecular mass markers are shown on the left. The arrow indicates the band presumed to be tPA revealed by casein zymography. (a) Lanes 1-6 contain $5 \mu$ of Meishan follicular fluid, while lanes 7-12 contain $5 \mu \mathrm{l}$ Large White follicular fluid, obtained before hCG. (b) Lanes 1-6 contain $5 \mu 1$ Meishan follicular fluid, while lanes 7-13 contain $5 \mu \mathrm{l}$ Large White follicular fluid, obtained after hCG. (c) Densitometry analysis of all samples. $\mathbf{\square}$, Large White before hCG; $⿴$, Large White after hCG; $\square$, Meishan before hCG; $\mathscr{Z}$, Meishan after hCG.

large follicles, pregnenolone may be converted to progesterone preferentially by $3 \beta-H S D$, resulting in a greater production of progesterone in Meishan gilts. However, the present data do not show any breed $\times$ time interaction for 
(a) Large White

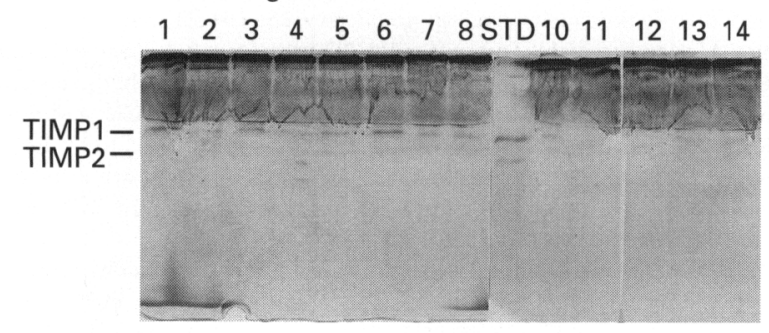

(b)

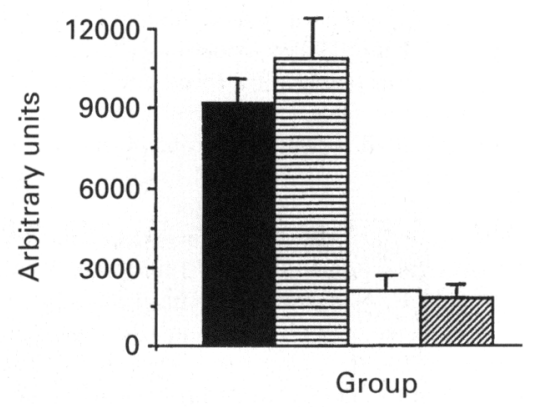

(c)

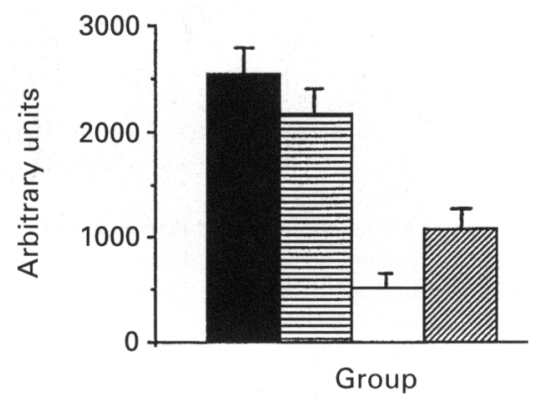

Fig. 6. (a) Visualization of tissue inhibitor of metalloproteinase 1 (TIMP-1) and TIMP-2 in the follicular fluid of Large White and Meishan gilts before and after hCG administration. Lanes $1-6,1 \mu 1$ Large White follicular fluid, obtained after hCG; lanes 7 and $8,1 \mu 1$ Large White follicular fluid, obtained before hCG; lane 9 (STD) TIMP standards; lanes 10 and 11, $1 \mu \mathrm{l}$ Meishan follicular fluid before hCG; lanes $12-14,1 \mu \mathrm{l}$ Meishan follicular fluid after hCG. Densitometry analysis of all samples for (b) TIMP-1 and (c) TIMP-2. D, Large White before hCG; $⿴$, Large White after hCG; $\square$, Meishan before hCG; $\mathbb{Z}$, Meishan after hCG.

these enzymes. The present study also demonstrated that, after hCG administration, the adrenodoxin immunoreactivity of granulosa cells and the $3 \beta-H S D$ immunoreactivity of theca cells were increased in Meishan and Large White gilts. In conclusion, these results do not support the hypothesis that the faster luteinization of Meishan follicles after an LH-hCG surge is related to differences in steroidogenic enzymes.

Since there are no differences between Meishan and Large White breeds in follicular sensitivity to LH (Biggs et al., 1993), it may be that autocrine-paracrine regulations of $\mathrm{LH}$ induced steroidogenesis by growth factors after $\mathrm{LH}$ administration differ between the two breeds. Since the bioavailability of growth factors commonly requires proteolysis (Flaumenhaft and Rifkin, 1992), the control of follicular proteolysis in the two breeds was explored. Follicular proteolysis involves two families of proteases (plasminogen activators and collagenases) and two families of inhibitors (plasminogen activator inhibitor and TIMPs) (Matrisian, 1992). Most of the members of these families were compared in Meishan and Large White follicles before and after hCG administration. Earlier observations in pig follicular fluid (Politis et al., 1990) showed that tissue-type plasminogen activator (tPA) and PAI-1 were present in follicular fluid from large follicles and were modulated differently by LH administration. In addition, Smith et al. (1994) demonstrated that TIMP-1 was also present in follicular fluid and that the amounts of a TIMP-1-like protein could be increased by LH. The present study extends these earlier findings by providing a comprehensive approach of the proteolytic cascade and by comparing it between Meishan and Large White follicles.

The present study also confirmed several earlier findings regarding the plasmin generation system. First, the main plasminogen activator in pig follicular fluid was shown to be tPA (Politis et al., 1990) by the presence of a lytic band at 80 $\mathrm{kDa}$, the molecular mass of tPA. In contrast, no signal at a lower molecular mass corresponding to urokinase-type plasminogen activator (uPA) was present in either breed. Second, the plasmin generation system appeared to be sensitive to hCG, as reported by Politis et al. (1990). Although this was not obvious for tPA, owing to a short interval between hCG adminstration and sampling of follicular fluid, PAI-1 appeared to be affected by hCG. The induction of PAI1 by hCG was more marked in Meishan follicles than in Large White follicles. Overall, the higher amounts of tPA found in Large White follicular fluid, together with the relative inability of hCG to induce PAI-1 in this breed (as opposed to what happens in Meishan follicles) may result in a higher supply of plasmin in Large White follicular fluid, particularly after hCG. Since plasmin is known to activate latent TGF $\beta$ (Lyons et al., 1990), and since TGF $\beta$ inhibits progesterone synthesis (Kubota et al., 1994), the end result may be a limitation of luteinization in Large White follicles.

A number of new findings regarding MMPs and TIMPs were made in the present study, extending earlier reports (Smith et al., 1994). First, a high molecular mass gelatinase (at $92 \mathrm{kDa}$ ), possibly MMP-9, was shown to be the major MMP present in follicular fluid from large healthy follicles. No other lower molecular mass gelatinases, typical of atretic follicles (Garcia et al., 1997) could be observed. As reported in sheep (Russel et al., 1995), the amounts of the $92 \mathrm{kDa}$ gelatinase were increased after hCG administration. The hCG increase in the $92 \mathrm{kDa}$ gelatinase was sevenfold stronger in Meishan follicles than in Large White follicles. Whether similar changes occur within the theca-granulosa cell layers remains to be established. Second, neither TIMP-2 nor TIMP-1 were increased in follicular fluid $16 \mathrm{~h}$ after hCG compared with the pre-injection amounts. While this is the first report of TIMP-2 amounts in pig follicular fluid, the lack of induction of TIMP-2 by hCG is in agreement with an earlier report in sheep (Russel et al., 1995). The lack of increase in amounts of TIMP-1 after hCG administration contrasts with another report in pigs (Smith et al., 1994). A shorter time lag between hCG injection and ovariectomy in the present 
study ( $16 \mathrm{~h}$ versus $24 \mathrm{~h}$ ) may explain this discrepancy. Third, clear breed differences in the changes in the amounts of TIMP-1 and TIMP-2 were observed both before and after hCG administration. Whatever the stage relative to hCG administration, Meishan follicles contained very limited amounts of TIMP- 1 and TIMP-2. The interpretation of these data is complicated by the fact that the amounts of TIMP-1 and TIMP-2 present in follicular fluid may not indicate accurately the amounts actually present within the follicular cells. However, our present working hypothesis is as follows. Since TIMP-1 and TIMP-2 bind and inactivate matrix metalloproteases (Matrisian, 1992), the lower amounts of these inhibitors in Meishan follicles are likely to increase the bioactivity of matrix MMPs in Meishan follicles. Since hCG has a stronger stimulatory effect on the amounts of matrix MMPs in Meishan follicles, high amounts of bioactive matrix MMPs may be present in Meishan follicular fluid after hCG administration. The physiological consequences of this increased MMP may be an increased availability of IGF-I after IGF binding protein (IGFBP) proteolysis (Fowlkes et al., 1994). The resulting high amounts of IGF-I released from IGFBP would then stimulate progesterone production by ovarian cells more efficiently in Meishan follicles (Caubo et al., 1989; Urban et al., 1990).

The authors would like to thank the staff of the pig units at St Gilles and Nouzilly for the supply of animals. The supply of the PAI-1 antibody by B. R. Downey (McGill University) is gratefully acknowledged. The help of D. Guillaume with statistical analysis of the data was appreciated.

\section{References}

Anderson LH, Christenson LK, Christenson RK and Ford SP (1993) Investigations into the control of litter size in swine II. Comparisons of morphological and functional embryonic diversity between Chinese and American breeds Journal of Animal Science 71 1566-1576

Ashworth CJ, Haley CS and Wilmut I (1992) Effect of Regumate on ovulation rate, embryo survival and conceptus growth in Meishan and Landrace $\times$ Large White gilts Theriogenology 37 433-443

Bazer FW, Thatcher WW, Martinat-Botté $F$ and Terqui M (1988) Conceptus development in Large White and Prolific Chinese MS pigs Journal of Reproduction and Fertility 84 37-42

Bazer FW, Thatcher WW, Martinat-Botté F, Terqui M, Lacroix MC, Bernard S, Revault M and Dubois DH (1991) Composition of flushings from Large White and prolific Chinese Meishan gilts Reproduction, Fertility, Development $351-63$

Biggs C, Tilton JE, Craigon J, Foxcroft GR, Ashworth CJ and Hunter MG (1993) Comparison of follicular heterogeneity and ovarian characteristics in Meishan and Large White hybrid pigs Journal of Reproduction and Ferfility 97 263-269

Biswas SB, Hammond RW and Anderson LD (1988) Fibroblast growth factors from bovine pituitary and human placenta and their functions in the maturation of porcine granulosa cells in vitro. Endocrinology 123 559-566

Bolet G, Martinat-Botté F, Locatelli A, Guiard J, Terqui M and Berthelot F (1986) Components of prolificacy in hyperprolific Large White sows compared with the Meishan and Large White breeds Genetique, Selection, Evolution 18 333-342

Camous S, Prunier A and Pelletier J (1985) Plasma prolactin, LH, FSH and estrogen excretion in gilts during sexual development fournal of Animal Science 60 1308-1317

Caubo B, DeVinna RS and Tonetta SA (1989) Regulation of steroidogenesis in cultured porcine theca cells by growth factors Endocrinology 125 321-326

Chang SCS, Jones JD, Ellefoon RD and Ryan RJ (1976) The porcine ovarian follicle: selected chemical analysis of follicular fluid at different developmental stages Biology of Reproduction 15 321-328
Conley AJ, Howard HJ, Slanger WD and Ford JJ (1994) Steroidogenesis in the preovulatory porcine follicle Biology of Reproduction 51 655-661

Conley AJ, Kaminski MA, Dubowsky SA, Jablona-Shariff A, Redmer DA and Reynolds LP (1995) Immunohistochemical localization of $3 \beta$-hydroxysteroid dehydrogenase and P450 17 $\alpha$-hydroxylase during follicular and luteal development in pigs, sheep, and cows Biology of Reproduction 52 1081-1094

Downey BD and Driancourt MA (1994) Morphological and functional characteristics of preovulatory follicles in Large White and Meishan gilts Journal of Animal Science 72 2099-2106

Driancourt MA, Gormon T, Phan Thanh L and Boomarov O (1996) Analysis by two dimensional electrophoresis of proteins secreted by sheep ovarian follicles: effects of the $F e c B$ gene, follicle size and atresia Journal of Reproduction and Fertility 107 69-77

Einarsson S and Rojkittikhun T (1993) Effects of nutrition on pregnant and lactating sows Journal of Reproduction and Fertility Supplement 48 229-239

Evans G, Dobias M, King GJ and Armstrong DT (1981) Estrogen, androgen and progesterone biosynthesis by theca and granulosa of preovulatory follicles in pigs Biology of Reproduction 25 673-682

Fisher SJ and Werb Z (1990) The catabolism of extracellular matrix components. In Extracellular Matrix: A Practical Approach pp 323-347 Eds MA Haralson and JR Hassel. PAS, London

Flaumenhaft R and Rifkin DB (1992) The extracellular regulation of growth factor action Molecular Biology of the Cell 3 1057-1065

Fowlkes JL, Suzuki K, Nagase H and Thrailkill KM (1994) Proteolysis of insulin like growth factor binding protein 3 during rat pregnancy: a role for matrix metalloproteinases Endocrinology 135 2810-2813

Foxcroft GR and Hunter MG (1985) Basic physiology of follicular maturation in the pig Journal of Reproduction and Fertility Supplement 33 1-19

Garcia R, Ballesteros LM, Hernandez Perez O, Rosales AM, Espinosa R, Soto H, Diaz de Leon L and Rosado A (1997) Metalloproteinase activity during growth, maturation and atresia in the ovarian follicles of the goat Animal Reproduction Science 47 211-228

Gore Langton RE and Armstrong DT (1988) Follicular steroidogenesis and its control. In The Physiology of Reproduction pp 332-369 Eds E Knobil and J Neill. Raven Press, New York

Guthrie HD, Barber JA, Leighton JK and Hammond JM (1994) Steroidogenic cytochrome $\mathrm{P} 450$ enzyme messenger ribonucleic acids and follicular fluid steroids in individual follicles during preovulatory maturation in the pig Biology of Reproduction $\mathbf{5 1}$ 465-471

Haley CS and Lee GJ (1993) Genetic basis of prolificacy in Meishan pigs Journal of Reproduction and Fertility Supplement 48 247-259

Henkeshoven J and Dernick R (1985) Simplified method for silver staining of proteins in polyacrylamide gels and the mechanism of silver staining Electrophoresis 6 103-114

Hermier D, Forgez P and Chapman MJ (1985) A density gradient study of the lipoproteins and apolipoproteins in the chicken Gallus domesticus. Biochimica et Biophysica Acta 836 105-111

Huet C, Monget P, Pisselet C and Monniaux D (1997) Changes in extracellular matrix components and steroidogenic enzymes during growth and atresia of antral ovarian follicles in the sheep Biology of Reproduction $\mathbf{5 6}$ 1025-1034

Hunter MG, Biggs C and Faillace LS (1993) Endocrine and follicular studies in Meishan pigs Journal of Reproduction and Fertility Supplement $\mathbf{4 8}$ 261-270

Hunter MG, Biggs C, Pickard AR and Faillace LS (1994) Differences in follicular aromatase activity between Meishan and Large White hybrid gilts Journal of Reproduction and Fertility 101 139-144

Hunter MG, Picton HM, Biggs C, Mann GE, McNeilly AS and Foxcroft GR (1996) Periovulatory endocrinology in high ovulating Meishan sows Journat of Endocrinology 150 141-147

Kubota T, Kamada S, Taguchi M and Aso T (1994) Autocrine/paracrine function of transforming growth factor $\beta 1$ in porcine granulosa cells Human Reproduction $92118-2122$

Lahteenmaki P, Lobo R, Marrs R, Gibbons WE, Nakamura K and di Zerega GS (1982) Characterization of porcine granulosa cells by isopycnic gradient centrifugation Biology of Reproduction 27 663-640

Legault C and Caritez JC (1983) L'expérimentation sur le porc chinois en France I. Perfomances de reproduction en race pure et en croisement Génétique Sélection Evolution 15 225-240

Lowry OH, Rosenbrough NJ, Farr AL and Randall RJ (1951) Protein measurement with the folin phenol reagent Journal of Biological Chemistry $193265-271$

Lyons RN, Gentry LE, Purchio AF and Moses HL (1990) Mechanisms of 
activation of latent recombinant transforming growth factor beta 1 by plasmin Journal of Cell Biology 110 1361-1367

Matrisian LM (1992) Metalloproteinases and their inhibitors in matrix remodelling Bioessays 14 455-463

Meduri G, Vuhai Luu Thi MT, Jolivet A and Milgrom E (1992) New functional zonation in the ovary as shown by immunohistochemistry of luteinizing hormone receptor Endocrinology 131 366-373

Meduri G, Vu Hai MT, Jolivet A, Takemori S, Kominami S, Driancourt MA and Milgrom E (1996) Comparison of cellular distribution of $\mathrm{LH}$ receptors and steroidogenic enzymes in the porcine ovary Journal of Endocrinology 148 $435-446$

Nicosia M, Moger WH, Dyer CA, Rack MM and Williams DL (1992) Apolipoprotein $E$ messenger RNA in rat ovary is expressed in theca and interstitial cells and presumptive macrophage but not in granulosa cells Molecular Endocrinology 6 978-988

Pharazyn A, Foxcroft GR and Aherne FX (1991) Temporal relationship between plasma progesterone concentrations in the utero-ovarian and jugular veins during early pregnancy in the pig Animal Reproduction Science 26323-332

Politis I, Srikandakumar A, Turner JD, Tsang BK, Ainsworth L and Downey BR (1990) Changes in and partial identification of the plasminogen activator and plasminogen activator inhibitor systems during ovarian follicular maturation in the pig Biology of Reproduction 43 636-642

Rajkumar K, Ly H, Schott PW and Murphy BD (1989) Use of low density and high density lipoproteins in undifferentiated granulosa cells Biology of Reproduction 41 855-861

Russel DL, Salamonsen LA and Findlay JK (1995) Immunization against the $\mathrm{N}$ terminal peptide of the inhibin $\alpha 43$ subunit $(\alpha \mathrm{N})$ disrupts tissue remodelling and the increase in matrix metalloproteinase 2 during ovulation Endocrinology 136 3657-3664

Simmen RCM, Simmen FA, Ko Y and Bazer FW (1989) Differential growth factor content of uterine luminal fluids from Large White and prolific Meishan pigs during the estrous cycle and early pregnancy Journal of Animal

\section{Science 67 1538-1544}

Smith MF, Kemper CN, Smith GW, Goetz TL and Jarrell VL (1994) Production of tissue inhibitor of metalloproteinases 1 by porcine follicular and luteal cells Journal of Animal Science 72 1004-1012

Stoklosowa S, Gregoraszuk E and Channing CP (1982) Estrogen and progesterone secretion by isolated cultured porcine thecal and granulosa cells Biology of Reproduction 26 943-952

Takayama M, Itoh S, Nagasaki T and Tanimizu I (1977) A new enzymatic method for the determination of serum choline containing phospholipids Clinica Chimica Acta 19 1350-1356

Tsang BK, Ainsworth L, Downey BD and Marcus GJ (1985) Differential production of steroids by dispersed granulosa and theca interna cells from developing preovulatory follicies of pigs Journal of Reproduction and Fertility $74459-470$

Urban RJ, Garmey JC, Shupnik MA and Veldhuis JD (1990) Insulin-like growth factor type I increases concentrations of messenger RNA encoding cytochrome P450 cholesterol side chain cleavage enzyme in primary cultures of porcine granulosa cells Endocrinology 127 2481-2488

Veldhuis JD, Gwynne JT, Strauss JF and Demers LM (1984) Role of estradiol as a biological amplifier of gonadotropin action in the ovary: in vitro studies using swine granulosa cells and homologous lipoproteins Endocrinology 114 2312-2319

Wilmut I, Ritchie WA, Haley CS, Ashworth CJ and Aitken RP (1992) A comparison of rate and uniformity of embryo development in Meishan and European White pigs Journal of Reproduction and Fertility 95 45-52

Zak LJ, Cosgrove JR, Aherne FX and Fowcroft GR (1997) Pattern of feed intake and associated metabolic and endocrine changes differentially affect postweaning fertility in primiparous lactating sows Journal of Animal Science $75208-216$ 